\title{
Efficacy and safety of povidone iodine with dimethyl sulfoxide vs $0.05 \%$ tretinoin in treatment of molluscum contagiosum: A randomized case control study
}

\section{Rai G Subodha Kumar, Nagesha Parvathi, Rangegowda Suresh, Niruvappa Vinay, Ittigi Vivekananda}

Department of Dermatology Venereology and Leprosy, Hassan Institute of Medical Sciences, Karnataka, India

Corresponding author: Nagesha Parvathi, MD, E-mail: drparvathicn@gmail.com

\begin{abstract}
Background: $\mathrm{MC}$ is an infection caused by a poxvirus. It is a self limiting condition, active therapy needed to prevent further spread, relieve symptoms, to prevent scarring and for cosmetic and social reasons. Methods: 40 patients were randomly divided into 2 groups; 20 each for Povidone Iodine with DMSO and 0.05\% Tretinoin cream. The given medication was applied at bed time over molluscum lesions. The assessment of response and side effects were performed weekly for 4 weeks. Results: At the end of 4 weeks, the mean lesion count decreased from $6.45 \pm 3.60$ SD to $4.25 \pm 3.76$ SD and from 6.85 4 4.08 SD to 3.60 44.76 SD in patients treated with Povidone Iodine and $0.05 \%$ Tretinoin cream respectively. Conclusion: Tretinoin showed fast recovery, lesions were resolved before 4 weeks. In Povidone Iodine with DOMS showed delayed response and even some of lesion extended beyond 4 weeks but the side effect were less.
\end{abstract}

Key words: MC-molluscum contagiosum.DMSO-dimethyl sulfoxide, SD-standard

\section{INTRODUCTION}

Molluscum contagiosum is an infection caused by a poxvirus (molluscum contagiosum virus). It is self-limited infectious dermatosis, frequent in paediatric population, sexually active adults, and immunocompromised individuals. It is caused by molluscum contagiosum virus (MCV) which is a virus of the Poxviridae family. MCV is transmitted mainly by direct contact with infected skin, which can be sexual, non-sexual, or autoinoculation [1].The lesions, known as Mollusca, are small, raised, dome shaped and usually pearly white, pink, or flesh-coloured with a dimple or pit in the centre. They often have a pearly appearance. They're usually smooth and firm. In most people, the lesions range from about the size of a pinhead to as large as 2 to 5 millimetres in diameter. They may become itchy, sore, red, and/or swollen [2].
Mollusca may occur anywhere on the body including the face, neck, arms, legs, abdomen, and genital area, alone or in groups. The lesions are rarely found on the palms of the hands or the soles of the feet.

The disease is common, with an estimated prevalence of $5-11 \%$. The disease is rare under the age of 1 year, perhaps due to maternally transmitted immunity and a long incubation period. In hot countries where children are lightly dressed and in close contact with one another, spread within households is not uncommon. The age of peak incidence is reported as between 2 and 5 years. In cooler climates, however, spread within households is rare and infection may occur at a later age, perhaps correlated with the use of swimming pools and shared bathing facilities. A later incidence peak in young adults is attributable to sexual transmission with lesions more common in the genital area [2].

\footnotetext{
How to cite this article: Subodha Kumar RG, Parvathi CN, Suresh MR, Vinay KN, Vivekanandal. Efficacy and safety of povidone iodine with dimethyl sulfoxide vs $0.05 \%$ tretinoin in treatment of molluscum contagiosum: A randomized case control study. Our Dermatol Online. 2021;12(e):e63.

Submission: 26.02.2021; Acceptance: 08.07.2021

DOI: $10.7241 /$ ourd.2021e.63
} 
Treatment modalities that have been tried are caustic destruction by cantharidin, trichloroacetic acid, diluted liquefied phenol, Irritants like salicylic acid, adapalene, nitric oxide cream, potassium hydroxide, benzoyl peroxide, lemon myrtle oil, tea tree oil, Surgical irritation like cryotherapy, laser. Immunological modality like diphencyprone, imiquimod, interferon, cimetidine, intralesional immunotherapy and Surgical removal. All-trans-retinoic acid (tretinoin) is easily available as cream base thought to involve the induction of local irritation which damages the viral protein-lipid membrane [2].

Povidone iodine is used primarily in Dermatology as a surgical preparation, as it has been recognized as a broadspectrum, resistance-free biocidal agent for many years. Povidone iodine also has a long track record of safety and tolerability given its extensive history of use in the operating room. Although incompletely understood, it is likely that free iodine poisons electron transport, inhibits cellular respiration, destabilizes membranes, inhibits protein synthesis, and denatures nucleic acids. Although Povidone iodine kills micro-organisms including bacteria, viruses, yeasts, molds, fungi, and protozoa, it has scarcely been used for purposes outside of skin asepsis in Dermatology. DMSO is currently FDA approved for the treatment of interstitial cystitis. DMSO is also a very effective pharmaceutical vehicle, greatly enhancing percutaneous penetration when used in combination with other substances [3].

Although it is a self limiting condition, a decision may be made in favor of active therapy to prevent further spread, relieve symptoms, to prevent scarring and for cosmetic and social reasons. The current treatment modalities include physical destruction of the lesion by curettage, cryosurgery or manual expression and topical application of caustic agents such as trichloroacetic acid, cantharidin, silver nitrate etc [4]. These therapeutic approaches have to be undertaken in a hospital setup and are not well tolerated by children owing to substantial pain and fear. In addition, these can also result in scarring and abscess formation [5]. Topical application of povidine iodine solution and $0.05 \%$ Tretinoin cream are two relatively painless modalities that have been used. Although tretinoin $0.05 \%$ cream which is commonly used, have shown different efficacy and safety profile in different studies, there are very few studies using povidone iodine and comparing the two. Hence this study was undertaken in view of comparing the safety and efficacy of the above two modalities in treating molluscum contagiosum.

\section{MATERIALS AND METHODS}

Double blinded randomized control study was conducted among 40 patients who attended Out Patient Department (OPD) of Dermatology Venereology and Leprosy Department, Hassan Institute of Medical Sciences Hassan, during the period of august 2019 to January 2020. Patients with Molluscum contagiosum more than 1 year of age and not taken any treatment for past 3 months were included in the study. Pregnant, lactating women, patients with more than 25 lesions, patients with lesion involving eyelid, patients with secondary infection and those who have history of hypersensitivity to Povidine iodine or Tretinoin were excluded from the study.

40 patients satisfying inclusion and exclusion criteria were recruited irrespective of sex, duration and response of disease to previous therapies. 40 patients were allocated randomly to group 1 and 2 . In group 1 , 20 patients were treated with povidone iodine with dimethyl sulfoxide and in group 2: 20 patients were treated with $0.05 \%$ tretinoin.

A detailed history was obtained, and a thorough general, systemic and cutaneous examination was done. Information regarding age, sex, number of lesions, duration of illness, site of involvement, family history, history of atopy and previous treatment were collected. Patients were randomly divided into two groups; 20 each for povidone iodine with dimethyl sulfoxide solution and $0.05 \%$ Tretinoin cream group.

Parents or guardians were advised to apply petroleum jelly around the lesions followed by application of the above medication to the centre of the lesion using a cotton swab, to be applied once every day at bed time for 4 weeks. If accidental spillage occurred, they were advised to wash the skin with water immediately. Parents were asked to report local (erythema, itching, burning, pain, erosion, crusting) and systemic (fever, flu like illness, diarrhoea, mylagia) side effects immediately. Follow up assessment was done every week for 4 weeks. At each follow up visit, clinical assessment of lesion, photographic assessment of lesion and any side effects were noted.

Efficacy assessment was done by weekly examination of patient every week for 4 weeks. In each visit complete remission of number of lesions were noted in both groups and photographic assessment was done. Photographic assessment was done based on resolution 
of number of lesion in each follow up visit for 4 weeks. Any side effects present were noted at each visit.

\section{Statistical Analysis}

Data was entered in Microsoft Excel and SPSS software was used for the analysis.

Results were expressed in percentages and proportions. Chi- square test, unpaired T- test, was used for analysis

\section{Ethics Statement}

Study was conducted after taking ethical committee clearance.

\section{RESULTS}

Total of 40 cases were included in study, 20 patients in povidine iodine with DMSO group and other 20 patients in $0.05 \%$ tretinoin group. Average age of patients were 24.15 years and 20.95 years in tretinoin and povidine iodine group respectively $(\mathrm{p}=0.53)$. Duration and average number of lesions in tretinoin group were 57.50 and 7.10 and in povidine group 65.75 and 6.40 respectively which was not statistically significant ( $p$ value $0.74 \mathrm{v} / \mathrm{s} 0.57$ ). Among 20 patients in tretinoin group, 8 were males $(40 \%)$ and 12 were females (60\%). Among 20 patients in Povidine iodine group 9 were males (45\%) and 11 were females (55\%) ( $\mathrm{P}$ value is 0.74$)$; (Tablel).

Among 20 patients in tretinoin group 1, patient was having lesions over arm (5\%), l patient was having lesions over chest (5\%), 14 patients were having lesions over face $(70 \%), 2$ patients each were having lesions over neck and genitals (10\% each). Among 20 patients, 2 patients were having lesions over arms (10\%), 1 was having lesions over chest (5\%), 14 were having lesions over face $(70 \%)$, l was having lesions over genital $(5 \%)$ and 2 were having lesions over neck(10\%). This difference between groups was not statistically significant ( $\mathrm{P}$ value is 0.98 ); (Table 1 ).

Among 40 patients, no one was having any symptoms associated with molluscum contagiosum. Out of 40 patients, one patient in povidone iodine group (5\%) was HIV positive $(\mathrm{P}$ value $=0.235)$.

Average number of basal lesions in tretinoin group was 6.85 and in povidone iodine group was 6.45 ( $\mathrm{P}$ value is 0.74 ). At the end of first week average number of lesions in tretinoin group was 6.45 and in povidine group 6.30 . There was no statistically significant difference between 2 groups at the end of first week $(P$ value $=0.90)$. In second week, in tretinoin group average lesion number was 6.15 compared to 5.80 in povidone iodine group $(\mathrm{P}$ value $=0.77)$. In the third week, tretinoin group average lesion count was 4.85 and 4.75 in povidone iodine group (P value 0.93). In fourth week lesion count in tretinoin group reduced to 3.60 compared to 4.25 in povodine group ( $\mathrm{P}$ value is 0.63 ); (Table 2 ).

In tretionin group 137 lesions were there in baseline, that decreased to $129,123,99$ and 72 in $1^{\text {st }}, 2^{\text {nd }}, 3^{\text {rd }}$ and $4^{\text {th }}$ week respectively and in povidone iodine group 129 lesions were present in baseline which decreased to 123 , 113,92 and 85 in $1^{\text {st }}, 2^{\text {nd }}, 3^{\text {rd }}$, and $4^{\text {th }}$ week respectively. Difference between number of lesions in 2 groups at each week was not statistically significant.(Table 3).

Table 1 : Basic demographic data in both groups

\begin{tabular}{lll}
\hline Parameter & Tretinoin group & $\begin{array}{l}\text { Povidone iodine } \\
\text { group }\end{array}$ \\
\hline $\begin{array}{l}\text { Number of patients } \\
\text { Average number of lesions per } \\
\text { patient }\end{array}$ & $7.1 \pm 4.11$ & 20 \\
Sex & Female -8 & $6.4 \pm 3.65$ \\
& Males -12 & Females -9 \\
Mean age & $24.15 \pm 16.16$ & Males -11 \\
Mean duration & $57.5 \pm 80.77$ days & $65.75 \pm 80.53$ days \\
Site of lesions & Arm -1 & Arm -2 \\
& Chest -1 & Chest -1 \\
& Face -14 & Face -14 \\
& Genital -2 & Genital -1 \\
& Neck -2 & Neck -2 \\
\hline
\end{tabular}

Table 2 : Improvement with treatment in each group

\begin{tabular}{lccccc}
\hline Week & \multicolumn{2}{c}{ Tretinoin group } & & \multicolumn{2}{c}{ Povidone iodine group } \\
\cline { 2 - 3 } \cline { 5 - 6 } & $\begin{array}{c}\text { Average } \\
\text { number }\end{array}$ & $\begin{array}{c}\text { Percentage } \\
\text { improvement }\end{array}$ & & $\begin{array}{c}\text { Average } \\
\text { number }\end{array}$ & $\begin{array}{c}\text { Percentage } \\
\text { improvement }\end{array}$ \\
\hline 1 week & 6.45 & $5.79 \%$ & & 6.30 & $2.12 \%$ \\
2 week & 6.15 & $11.62 \%$ & & 5.8 & $8.62 \%$ \\
3 week & 4.85 & $36.12 \%$ & & 4.75 & $22.97 \%$ \\
4 week & 3.6 & $57.33 \%$ & & 4.25 & $30.34 \%$ \\
\hline
\end{tabular}

Table 3: Weekly lesion counts

\begin{tabular}{|c|c|c|c|}
\hline \multicolumn{4}{|c|}{ Total lesion counts } \\
\hline & Baseline & 1 Week & \\
\hline Tretion & 137 & 129 & 0.943 \\
\hline \multirow[t]{2}{*}{ Podovine } & 129 & 123 & \\
\hline & Baseline & 2 Week & \\
\hline Tretion & 137 & 123 & 0.890 \\
\hline \multirow[t]{2}{*}{ Podovine } & 129 & 113 & \\
\hline & Baseline & 3 Week & \\
\hline Tretion & 137 & 99 & 0.944 \\
\hline \multirow[t]{2}{*}{ Podovine } & 129 & 92 & \\
\hline & Baseline & 4 Week & \\
\hline Tretion & 137 & 72 & 0.262 \\
\hline Podovine & 129 & 85 & \\
\hline
\end{tabular}


In tretionin group 137 lesions were there in baseline, that decreased to $129,123,99$ and 72 in $1^{\text {st }}, 2^{\text {nd }}, 3^{\text {rd }}$ and $4^{\text {th }}$ week respectively, $\mathrm{P}$ value is $<0.001$ it is statistically significant. 2 patients achieved complete resolution by $3^{\text {rd }}$ week and 6 patients by $4^{\text {th }}$ week. 12 patients did not achieve complete resolution in tretinoin group, $\mathrm{P}$ value is 0.16 (Table 4 and Table 5).

In povidone iodine group 129 lesions were present in baseline which decreased to $123,113,92$ and 85 in $1^{\text {st }}$, $2^{\text {nd }}, 3^{\text {rd }}$, and $4^{\text {th }}$ week respectively, $p$ value is 0.008 which is statistically significant. Complete resolution was only observed in 4 patients in $4^{\text {th }}$ week. 16 patients did not achieve complete resolution in povidone iodine group, $\mathrm{P}$ value is 0.16 (Table 4 and Table 5).

Percentage of improvement in tretinoin and Povidone iodine group was $5.79 \% \mathrm{v} / \mathrm{s} 2.12 \%, 11.63 \% \mathrm{v} / \mathrm{s} 8.62 \%$, $36.12 \% \mathrm{v} / \mathrm{s} 22.97 \%, 57.33 \% \mathrm{v} / \mathrm{s} 30.34 \%$ in first week, second week, third week and fourth week respectively. This difference between two groups in each week was found to be not significant ( $p$ value $0.12,0.68,0.42$, 0.20); (Graph 1).

Patients only had mild tolerable side effects. Erythema was seen in 1 patient (5\%), after one week of tretinoin use ( $\mathrm{P}$ value is 0.235$)$. In the third week 7 patients $(35 \%)$, in tretinoin group developed erythema and this was found to be statistically significant $(P$ value $=0.01)$. Similar findings were noticed at the end of fourth week also (Table 6).

Table 4: Complete lesion resolution.

\begin{tabular}{lccc}
\hline \multicolumn{4}{c}{ Complete Resolution of lesion } \\
\hline & Tretion & Povodine & P \\
\hline Complete & 8 & 4 & 0.167 \\
Incomplete & 12 & 16 & \\
Total & 20 & 20 & \\
\hline
\end{tabular}

Table 5: Comparison of weekly lesion count in each group.

\begin{tabular}{lcccccc}
\hline \multicolumn{7}{c}{ Compare lesion count weekly } \\
\hline & BL & 1 WEEK & 2 WEEK & 3 WEEK & 4 WEEK & P \\
\hline TRETION & 137 & 129 & 123 & 99 & 72 & $<0.001$ \\
POVODINE & 129 & 123 & 113 & 92 & 85 & 0.008 \\
\hline
\end{tabular}

Erosion was noticed in 1 patient of tretinoin group (5\%) in third week of treatment (P value 0.235 ). No ulcer or dryness was noticed in either of the group. Burning sensation was seen in 2 patient (10\%) of tretinoin group and 1 patient $(5 \%)$ of povidone iodine group ( $\mathrm{P}$ value $0.54)$. In second week, 2 patients ( $10 \%)$ of both group developed burning sensation ( $\mathrm{P}$ value is 1 ).

3 patients (15\%) from tretinoin group and 2 patients (10\%) from povidone iodine group developed burning sensation in fourth week $(\mathrm{P}=0.63)$.

4 patients $(20 \%)$ in tretinoin group developed scaling in third week which was found to be significant $(\mathrm{P}=0.014)$.

\section{DISCUSSION}

$\mathrm{MC}$, although medically benign, is a rapidly transmissible viral infection that can be cosmetically disfiguring, painful, socially stigmatizing and can become secondarily infected. The most commonly utilized treatment is the in-office application of cantharidin, causing selective intraepidermal acantholysis, inducing a blister at the involved skin site. Local destruction can also be achieved via curettage, laser, cryotherapy, or needle extraction, but these are painful and not tolerated well by children. Lesion eradication may also be chemical (trichloroacetic acid, phenol, tretinoin), or immunologic (Imiquimod), inciting an inflammatory

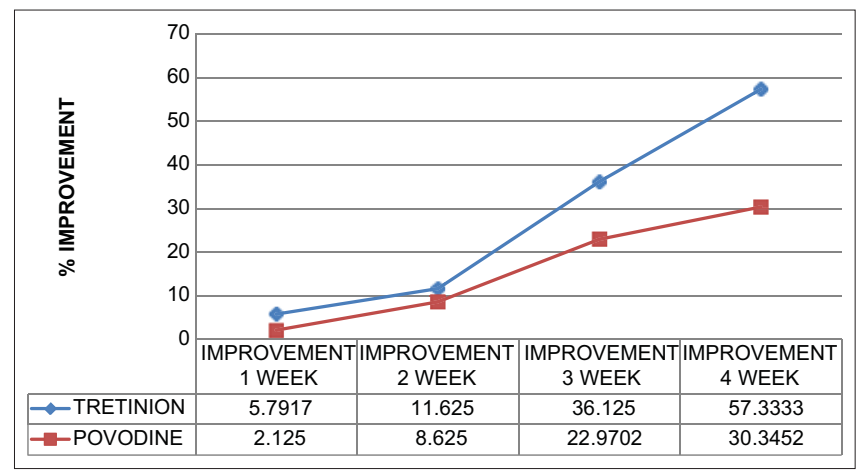

Graph 1: Weekly percentage improvement in each group.

Table 6 : Side effects in each group

\begin{tabular}{|c|c|c|c|c|c|c|c|c|}
\hline & \multicolumn{2}{|c|}{$1 \mathrm{wk}$} & \multicolumn{2}{|c|}{$2 w k$} & \multicolumn{2}{|c|}{$3 w k$} & \multicolumn{2}{|c|}{$4 w k$} \\
\hline & $\begin{array}{l}\text { Tretinoin } \\
\text { group }\end{array}$ & $\begin{array}{c}\text { Povidone } \\
\text { iodine group }\end{array}$ & $\begin{array}{l}\text { Tretinoin } \\
\text { group }\end{array}$ & $\begin{array}{c}\text { Povidone } \\
\text { iodine group }\end{array}$ & $\begin{array}{l}\text { Tretinoin } \\
\text { group }\end{array}$ & $\begin{array}{c}\text { Povidone } \\
\text { iodine group }\end{array}$ & $\begin{array}{l}\text { Tretinoin } \\
\text { group }\end{array}$ & $\begin{array}{c}\text { Povidone } \\
\text { iodine group }\end{array}$ \\
\hline Erythema & 1 & 0 & 1 & 0 & 7 & 0 & 7 & 0 \\
\hline Erosion & 0 & 0 & 0 & 0 & 1 & 0 & 1 & 0 \\
\hline Scaling & 0 & 0 & 0 & 0 & 4 & 0 & 4 & 0 \\
\hline Burning sensation & 2 & 1 & 2 & 2 & 3 & 2 & 3 & 2 \\
\hline Itching & 0 & 0 & 0 & 0 & 1 & 0 & 1 & 0 \\
\hline
\end{tabular}


response which upregulates the immune system to clear the infection. Topical cidofovir has been used in the immunosuppressed population, but has not been systemically studied in the general population. Currently, there are no United States Food and Drug Administration (FDA)-approved prescription drugs for MC.

In 2017 Caproitic et al [3] conducted a case series of 12 patients with Molluscum Contagiosum treated with povidone iodine with DMSO twice daily application for 4 weeks. Among total 115 lesions, complete resolution of 103 was noticed (90\%). Out of 12 patients, 4 patients had complete resolution in 4 weeks, 4 had complete resolution in 8 weeks and no complete resolution was noticed in 4 patients. In our study among 20 patients in povidone iodine group 4 had complete resolution in $4^{\text {th }}$ week an complete resolution was not observed at $1^{\text {st }}, 2^{\text {nd }}$ and $3^{\text {rd }}$ week follow-ups. When total number of lesions in povidone iodine group were considered 129 lesions were present in baseline that was decreased to $123,113,92$ and 85 in $1^{\text {st }}, 2^{\text {nd }}, 3^{\text {rd }}$ and $4^{\text {th }}$ week respectively

Rajouria et al in 2011 [6] conducted randomized trial to compare the $5 \% \mathrm{KOH}$ cream with $0.05 \%$ Tretinoin cream once daily night application. 50 patients were included in the study, 25 in each group. At 4weeks lesion count decreased in both the groups. In $\mathrm{KOH}$ group lesion resolution was faster compared to tretinoin group and fewer side effects were seen in tretinoin group which was similar to that observed in our study.

Emily Forbet et al. [7] published a review and update on management of Molluscum contagiosum where retinoids are mentioned as potential modality of treatment.

Overall tolerability was excellent, with only two patients demonstrating mild irritation in the form of dryness of the surrounding skin at application site. Only less number of patients in our study had side effects in the form of burning sensation.

\section{Limitations}

Small sample size and lesser duration of follow-up were limitations of this study.

\section{CONCLUSION}

The result of both Povidone Iodine and Tretinoin showed good response, well tolerated but between the two, Tretinoin showed fast recovery and most lesions resolved before 4 weeks. The side effects could be minimized if applied as stated above. On the other hand, Povidone Iodine in DMSO showed delayed response and even some of lesion extended beyond 4 weeks but the side effect were less, and hence can be used in recurrent cases and in children.

\section{REFERENCES}

1. Meza-Romero R, Navarrete-Dechent C, Downey C. Molluscum contagiosum: an update and review of new perspectives in etiology, diagnosis, and treatment. Clin CosmetInvestig Dermatol. 2019;12:373-81.

2. Leung AKC, Barankin B, Hon KLE. Molluscum Contagiosum: An Update. Recent Pat Inflamm Allergy Drug Discov. 2017;11:22-31.

3. Capriotti K, Stewart K, Pelletier J, Capriotti J. Molluscum contagiosum treated with dilute povidone-iodine: a series of cases. The Journal of clinical and aesthetic dermatology. 2017;10:41.

4. Goyal V, Maheshwari AK, Goyal S, Gill M. A comparative study of efficacy of $10 \% \mathrm{KOH}$, trichloroacetic acid (TCA) and $0.05 \%$ tretinoin for the treatment of molluscum contagiosum. Sch J App Med Sci. 2014;2:1196-8.

5. van der Wouden JC, van der Sande R, Kruithof EJ, Sollie A, van Suijlekom-Smit LW, Koning S. Interventions for cutaneous molluscum contagiosum. Cochrane Database Syst Rev. 2017;5:CD004767.

6. Rajouria EA, Amatya A, Karn D. Comparative study of $5 \%$ potassium hydroxide solution versus $0.05 \%$ tretinoin cream for molluscum contagiosum in children. Kathmandu Univ Med J (KUMJ). 2011;9:291-4.

7. Forbat E, Al-Niaimi F, Ali FR. Molluscum Contagiosum: Review and Update on Management. Pediatr Dermatol. 2017;34:504-15.

Copyright by Rai G Subodha Kumar, et al. This is an open access article distributed under the terms of the Creative Commons Attribution License, which permits unrestricted use, distribution, and reproduction in any medium, provided the original author and source are credited.

Source of Support: Nil, Conflict of Interest: None declared. 